\title{
Primary acquired sideroblastic erythropoiesis in non-anaemic and minimally anaemic subjects
}

\author{
D T BOWEN, A JACOBS \\ From the Department of Haematology, University of Wales College of Medicine, Heath Park, Cardiff
}

SUMMARY Six patients had primary sideroblastic erythropoiesis together with a haemoglobin concentration of $12.0 \mathrm{~g} / \mathrm{dl}$ or higher. In four cases this was associated with macrocytosis. Other abnormalities included failure of erythroid progenitor growth from peripheral blood in three cases and occasional dysplastic appearances in neutrophils and megakaryocytes. Sideroblastic erythropoiesis seems to be an early manifestation of the myelodysplastic syndrome and may present clinically at a pre-anaemic stage.

The clinical syndrome of primary acquired sideroblastic anaemia (PASA) with its striking bone marrow morphological detail has been recognised for many years, ' and, more recently, the condition has been included among the myelodysplastic syndromes by the French-American-British (FAB) cooperative group. ${ }^{2}$ It is now generally accepted that this disorder results from the clonal proliferation of abnormal haemopoietic stem cells that have undergone premalignant transformation. ${ }^{3}$ Although the FAB group do not define anaemia in relation to the diagnosis of myelodysplastic syndrome, patients with PASA usually seem to have decreased haemoglobin concentrations and in many cases are dependent on transfusion. ${ }^{4-7}$ Jacobs and Clark suggested that PASA, with its accompanying erythroid hyperplasia in bone marrow, ${ }^{8}$ may represent an early stage in a progressive preleukaemic evolution of the haemopoietic stem cell, and this is in keeping with the relatively good prognosis in this group of patients. We describe six non-anaemic or minimally anaemic subjects in whom erythropoiesis was dominated by the presence of ring sideroblasts in the bone marrow. The gross disturbances of erythropoiesis found in these patients in the presence of a relatively normal haemoglobin concentration, leucocyte count, and platelet count add weight to the suggestion that sideroblastic change represents an early manifestation of the preleukaemic process.

\section{Case reports}

CASE 1

A 68 year old retired engineer with a medical history of

Accepted for publication 4 August 1988 chronic obstructive airways disease, pneumonia in 1943, and an "ulcer" operation in 1972, was referred to the University Hospital of Wales after admission elsewhere for investigation of possible gastrointestinal bleeding. He had been a non-smoker for 20 years and drank little alcohol. Bone marrow aspiration carried out at the referring hospital showed sideroblastic haemopoiesis. On admission, direct questioning indicated symptoms of angina but there were no abnormal physical signs.

On admission to this hospital in July 1987, his haemoglobin concentration was $12.0 \mathrm{~g} / \mathrm{dl}$. The blood film showed some anisocytosis and macrocytes together with occasional hypogranular and bilobed neutrophils. Review of previous blood counts showed that he had been intermittently anaemic since 1984 with a haemoglobin concentration varying between 9.6 and $12.4 \mathrm{~g} / \mathrm{dl}$ and a mean cell volume varying from 79 to $96 \mathrm{fl}$. Serum ferritin concentration was $343 \mu \mathrm{g} / \mathrm{l}$, serum vitamin $B_{12} 573 \mathrm{ng} / \mathrm{l}$, serum folate $55 \mu \mathrm{g} / \mathrm{l}$, and red cell folate $1278 \mu \mathrm{g} / \mathrm{l}$. Blood urea, electrolytes, and liver functions tests yielded normal results.

A bone marrow aspirate was hypercellular with plentiful megakaryocytes and occasional micromegakarocytes. There were some dyserythropoietic changes. Other haematological variables are shown in the table. The bone marrow karyotype was $46 \mathrm{XY}$, though one cell with $46 \mathrm{XY} \operatorname{del}(7)$ (q32-qter) was found. A two week course of folic acid ( $5 \mathrm{mg}$ daily) and pyridoxine hydrochloride ( $200 \mathrm{mg}$ daily), together with an injection of hydroxocobalimin $(1000 \mu \mathrm{g})$ failed to produce any haematological change.

CASE 2

A 65 year old housewife was referred for investigation of persistent macrocytosis found on routine examination. She neither smoked nor drank alcohol and had 
Table Haematological data from six patients with sideroplastic erythropoiesis

\begin{tabular}{|c|c|c|c|c|c|c|c|}
\hline & Reference values & $\begin{array}{l}\text { Case I } \\
(M)\end{array}$ & $\begin{array}{l}\text { Case } 2 \\
(F)\end{array}$ & $\begin{array}{l}\text { Case } 3 \\
(\boldsymbol{M})\end{array}$ & $\begin{array}{l}\text { Case } 4 \\
(M)\end{array}$ & $\begin{array}{l}\text { Case } 5 \\
(F)\end{array}$ & $\begin{array}{l}\text { Case 6 } \\
(M)\end{array}$ \\
\hline $\begin{array}{l}\text { Peripheral blood: } \\
\text { Haemoglobin }\end{array}$ & \multirow{2}{*}{$\begin{array}{l}\text { Male } 13.5-16.5 \mathrm{~g} / \mathrm{dl} \\
\text { Female } 11.5-15 \cdot 5 \mathrm{~g} / \mathrm{dl} \\
80-100 \mathrm{fl} \\
4-10 \cdot 5 \times 10^{9} / 1 \\
1 \cdot 5-7 \cdot 5 \times 10^{9} / 1 \\
150-450 \times 10^{9} / 1 \\
35-400 / \mathrm{ml} \mathrm{blood} \\
5-308 / \mathrm{ml} \text { blood }\end{array}$} & $12 \cdot 0$ & $12 \cdot 0$ & $12 \cdot 0$ & $14 \cdot 0$ & $12 \cdot 1$ & $12 \cdot 2$ \\
\hline $\begin{array}{l}\text { Mean cell volume } \\
\text { White cells } \\
\text { Neutrophils } \\
\text { Platelets } \\
\text { BFU-E } \\
\text { CFU-GM }\end{array}$ & & $\begin{array}{c}96 \\
8 \cdot 3 \\
4 \cdot 0 \\
177 \\
0 \\
13\end{array}$ & $\begin{array}{c}106 \\
9 \cdot 0 \\
5 \cdot 5 \\
247 \\
94 \\
0\end{array}$ & $\begin{array}{c}114 \\
7 \cdot 8 \\
3 \cdot 3 \\
466 \\
0 \\
8\end{array}$ & $\begin{array}{c}99 \\
8 \cdot 4 \\
3 \cdot 4 \\
390 \\
37 \\
18\end{array}$ & $\begin{array}{c}102 \\
9 \cdot 0 \\
6 \cdot 3 \\
655 \\
0 \\
9\end{array}$ & $\begin{array}{c}102 \\
9 \cdot 0 \\
3 \cdot 9 \\
345 \\
54 \\
15\end{array}$ \\
\hline $\begin{array}{l}\text { Marrow: } \\
\% \text { Erythroblasts } \\
\% \text { Ring sideroblasts } \\
\% \text { Blasts }\end{array}$ & $\begin{array}{l}5-35 \\
\text { Nil } \\
0-3\end{array}$ & $\begin{array}{r}29 \\
45 \\
<1\end{array}$ & $\begin{array}{r}26 \\
80 \\
2\end{array}$ & $\begin{array}{r}35 \\
52 \\
2\end{array}$ & $\begin{array}{r}32 \\
78 \\
<1\end{array}$ & $\begin{array}{r}30 \\
53 \\
2\end{array}$ & $\begin{array}{r}43 \\
78 \\
1\end{array}$ \\
\hline $\begin{array}{l}\text { Ferrokinetics's: } \\
\text { Marrow iron turnover } \\
\% \text { Ineffective erythropoiesis }\end{array}$ & $\begin{array}{l}75-160 \mu \mathrm{mol} / \mathrm{l} / \mathrm{d} \\
10-30\end{array}$ & $\begin{array}{r}155 \\
37\end{array}$ & $\begin{array}{r}142 \\
68\end{array}$ & & & & \\
\hline
\end{tabular}

no specific symptoms. No abnormalities were found on examination.

Her haemoglobin concentration was $12.0 \mathrm{~g} / \mathrm{dl}$. Serum vitamin $B_{12}$ concentration was $640 \mathrm{ng} / 1$ and serum folate was $4 \cdot 2 \mu \mathrm{g} / \mathrm{l}$. The bone marrow aspirate was hypercellular with plentiful megakaryocytes and occasional micromegakaryocytes. Other haematological variables are shown in the table.

\section{CASE 3}

A 59 year old builder had had transient attacks of cardiac ischaemia six years before being seen at this hospital. At that time he had been thought to be polycythaemic with a haemoglobin concentration of $20.2 \mathrm{~g} / \mathrm{dl}$ and a mean cell volume of $119 \mathrm{fl}$. Red cell volume, however, had been $36.4 \mathrm{ml} / \mathrm{kg}$ body weight and plasma volume $32 \mathrm{ml} / \mathrm{kg}$ body weight: the bone marrow aspirate was said to have been megaloblastic at that time. He smoked 20 cigarettes daily. Treatment with vitamin $B_{12}$ and folic acid was accompanied by venesection on three occasions. He was reviewed regularly over the subsequent six years while his haemoglobin slowly fell, during which time he had stopped smoking.

On referral, his haemoglobin concentration was $12.0 \mathrm{~g} / \mathrm{dl}$, serum vitamin $B_{12}$ was $660 \mathrm{ng} / \mathrm{l}$, serum folate $3.7 \mu \mathrm{g} / \mathrm{l}$, and serum ferritin $480 \mu \mathrm{g} / \mathrm{l}$. Bone marrow aspirate was cellular with morphologically normal megakaryocytes. Additional haematological data are shown in the table. Cytogenetic analysis indicated a constitutional karyotype abnormality $(46 \mathrm{XY}, 16 \mathrm{p}+$ ).

\section{CASE 4}

A 60 year old miner was referred for investigation of chest pain and breathlessness. He smoked moderately and had a history of excessive alcohol intake until six months previously. His recent alcohol consumption was two pints of beer weekly. No abnormality was found on physical examination. $\mathrm{He}$ had a haemoglobin concentration of $14.0 \mathrm{~g} / \mathrm{dl}$. Serum vitamin $B_{12}$ was $789 \mathrm{ng} / \mathrm{ml}$, serum folate $2.8 \mu \mathrm{g} / \mathrm{l}$, red cell folate $363 \mu \mathrm{g} / 1$ and serum ferritin was $630 \mu \mathrm{g} / 1$. Gamma glutamyl transferase was $21 \mathrm{IU} / 1$.

Bone marrow aspiration showed a hypercellular marrow with morphologically normal megakaryocytes and no abnormality in the myeloid series. Additional haematological data are shown in the table. Treatment with pyridoxine $(150 \mathrm{mg}$ daily) and folic acid ( $5 \mathrm{mg}$ daily) for three weeks, together with hydroxocobalamin $(1000 \mu \mathrm{g})$ stat failed to change the peripheral blood count or bone marrow appearances.

\section{CASE 5}

A 72 year old woman was referred for investigation of persistent macrocytosis that was discovered following an attack of labyrinthitis. She already had diabetes mellitus and mild hypertension, neither of which required treatment. She smoked 20 cigarettes a day and drank little alcohol. There were no abnormal findings on physical examination.

At presentation her haemoglobin concentration was $12 \cdot 1 \mathrm{~g} / \mathrm{dl}$. Serum $B_{12}$ concentration was $396 \mathrm{ng} / \mathrm{l}$, serum folate $4.6 \mu \mathrm{g} / \mathrm{l}$, and serum ferritin $334 \mu \mathrm{g} / 1$. Bone marrow aspirate was hypercellular with many dysplastic megakaryocytes. Many cells showed dyserythropoiesis. Cytogenetic analysis from blood and bone marrow showed a normal female karyotype (table).

CASE 6

An 84 year old man returned from abroad for hip surgery. Macrocytosis was noted on a routine blood 
count. He was fit and well and had no significant medical history. He denied excessive alcohol consumption, did not smoke, and took no medication. His haemoglobin concentration was $12 \cdot 2 \mathrm{~g} / \mathrm{dl}$. Serum vitamin $B_{12}$ was $428 \mathrm{ng} / \mathrm{l}$ and serum folate $19 \mathrm{nmol} / \mathrm{l}$. Bone marrow karyotype was $46 \mathrm{XO}$ in all metaphases. A blood sample was not obtained for cytogenetic analysis of peripheral blood (table).

\section{Discussion}

Primary acquired sideroblastic erythropoiesis is usually associated with anaemia. Cheng $e t$ al found a mean haematocrit of 0.27 in the 268 cases they reviewed. ${ }^{5}$ The 23 patients described by May et al $^{6}$ and the 37 patients described by Cazzola et $a l^{7}$ all had haemoglobin concentrations of less than $12.0 \mathrm{~g} / \mathrm{dl}$. We draw attention to the occurrence of sideroblastic erythropoiesis in patients with a haemoglobin concentration above this value. In four of our patients there was an unexplained macrocytosis resistant to treatment with vitamin $\mathbf{B}_{12}$ and folic acid and, in one case, examination of the peripheral blood showed dysplastic neutrophils despite a normal neutrophil count. In two patients the platelet count was above our normal reference range.

Further special investigations showed other haemopoietic abnormalities typical of patients with myelodysplastic syndromes. In three cases peripheral blood culture showed a failure of erythroid progenitors (BFU-E) to grow normally, and in one case there was a failure to grow granulocyte-macrophage colonies (CFU-GM) after 14 days' culture, despite apparently normal neutrophils in the peripheral blood. These findings are similar to those seen in cultures of bone marrow progenitors in myelodysplastic syndrome. ${ }^{910}$ In two cases where a ferrokinetic assessment of erythropoiesis was carried out the increased degree of ineffective erythropoiesis combined with a slight increase in total erythroid output was again typical of the findings in early myelodysplastic syndrome. ${ }^{10}$ Cytogenetic analysis of the bone marrow showed no clonal abnormalities in any case. Ras mutations in haemopoietic cells have been found in about $40 \%$ of patients with myelodysplastic syndrome." None was found in cases 1-4 in our group.

Five of our patients have been followed up. The longest follow up is four years with no haematological change. Case 2 has become anaemic after 18 months and case 3 dropped his haemoglobin concentration by $2 \mathrm{~g} / \mathrm{dl}$ three months after referral.

Oscier has suggested that the incidence of myelodysplastic syndrome may be about 1 in 4250 a year but that in those above the age of 55 years there may be a prevalence of the order of 1 in $462 . .^{12}$ These figures suggest that myelodysplastic syndrome is more common than might have been imagined. We do not know how long sideroblastic change had been present in our patients but the cases presented here illustrate the need for a high degree of suspicion in making an early diagnosis. The early identification of these patients is important as they are at risk of eventual evolution into a more hazardous clinical state. Cheng $e t$ al found that acute leukaemia occurred in $10 \%$ of the 268 patients with sideroblastic anaemia reviewed, ${ }^{5}$ and Todd and Pierre show that the seven year survival compared with an age and sex matched population was only $37 \%$ that of the controls. ${ }^{13}$ Similar data have been published by Oguma et al..$^{14}$ Erythroid abnormality associated with ring sideroblast formation seems to be an early manifestation of myelodysplastic syndrome.

DTB is supported by the Leukaemia Research Fund.

\section{References}

1 Bjorkman SD. Chronic refractory anaemia with sideroblastic bone marrow. A study of four cases. Blood 1956;11:250-9.

2 Bennett JM, Catovsky D, Daniel MT, et al. Proposals for the classification of the myelodysplastic syndromes. Br J Haematol 1982;51:189-99.

3 Jacobs A. Human preleukaemia: do we have a model? Br J Cancer 1987;55:1-5.

4 Dacie JV, Smith MD, White JC, Mollin DL. Refractory normoblastic anaemia: A clinical and haematological study of seven cases. Br J Haematol 1959;5:56-82.

5 Cheng DS, Kushner JP, Wintrobe MM. Idiopathic refractory sideroblastic anaemia; incidence and risk factors for leukaemic transformation. Cancer 1979;44:724-31.

6 May A, De Souza P, Barnes K, Kaaba S, Jacobs A. Erythroblast iron metabolism in sideroblastic marrows. $\mathrm{Br} \mathrm{J} \mathrm{Haematol}$ 1982;52:611-21.

7 Cazzola M, Barosi G, Gobbi PG, Invernizzi R, Riccardi A, Ascari E. Natural history of idiopathic sideroblastic anaemia. Blood 1988;71:305-12.

8 Jacobs A, Clark RE. Pathogenesis and clinical variations in the myelodysplastic syndromes. Clin Haematol 1986;15:925-52.

9 Ruutu T, Partanen S, Lintula R, Teerenhovi L, Kruatila S. Erythroid and granulocyte-macrophage colony formation in myelodysplastic syndromes. Scand J Haematol 1984;32: 395-402.

10 May SJ, Smith SA, Jacobs A, Williams A, Bailey-Wood R. The myelodysplastic syndrome: analysis of laboratory characteristics in relation to the FAB classification. Br $J$ Haematol 1985;59:311-19.

11 Padua RA, Carter G, Hughes D et al. Ras mutations in myelodysplasia detected by amplification, oligonucleotide hybridisation and transformation. Leukaemia 1988;2:503-10.

12 Oscier DG. Myelodysplastic syndromes. Clin Haematol 1987;1:389-426.

13 Todd WM, Pierre RV. Pre-leukaemia: a long term prospective study of 326 patients. Scand J Haematol 1986;36 (supplement 45):114-20.

14 Oguma S, Yoshida Y, Uchino H, Mackawa T. Factors influencing non leukaemic death in refractory anaemia, refractory anaemia with ring sideroblasts, and refractory anaemia with excess of blasts. Cancer Res 1987;47:3599-602.

15 Ricketts C, Jacobs A, Cavill I. Ferrokinetics and erythropoiesis in man: the measurement of effective erythropoiesis, ineffective erythropoiesis and red cell life span using ${ }^{59} \mathrm{Fe}$. Br J Haematol 1985;31:65-75.

Requests for reprints to: Dr DT Bowen, Department of Haematology, University of Wales College of Medicine, Heath Park, Cardiff CF4, Wales. 